\title{
Emergency HeartWare Ventricular Assist Device (HVAD) exchange due to pump thrombosis using minimally invasive technique
}

\author{
Remigiusz Antończyk ${ }^{1}$, Ewa Trejnowska², Jerzy Pacholewicz ${ }^{1}$, Tomasz Wolny², Paweł Nadziakiewicz², \\ Karolina Antończyk ${ }^{1}$, Izabela Copik ${ }^{1}$, Magdalena Piontek ${ }^{2}$, Małgorzata Jasińska², Krzysztof Filipiak ${ }^{1}$, \\ Maciej Głowacki ${ }^{3}$, Maciej Gawlikowski ${ }^{3}$, Marcin Borowicz ${ }^{1}$, Roman Kustosz ${ }^{3}$, Jacek Waszak ${ }^{1}$, Piotr Przybyłowski ${ }^{1}$, \\ Marian Zembala ${ }^{1}$, Michał Zakliczyński ${ }^{1}$, Michał Oskar Zembala ${ }^{1}$
}

\author{
${ }^{1}$ Department of Cardiac, Vascular and Endovascular Surgery and Transplantology, SMDZ in Zabrze, Medical University of Silesia \\ in Katowice, Silesian Centre for Heart Diseases, Zabrze, Poland \\ 2Department of Cardiac Anesthesiology and Intensive Care, SMDZ in Zabrze, Medical University of Silesia in Katowice, \\ Silesian Centre for Heart Diseases, Zabrze, Poland \\ ${ }^{3}$ Artificial Heart Laboratory, Foundation for Cardiac Surgery Development, Zabrze, Poland
}

Kardiochirurgia i Torakochirurgia Polska 2017; 14 (1): 76-78

\begin{abstract}
Left ventricular assist device (LVAD) thrombosis remains a dreadful complication of mechanical circulatory support, with an incidence of $8-12 \%$ depending on the pump type and patient's comorbidities. Fibrinolysis may be considered early in pump thrombosis, but when contraindicated a pump exchange remains the only alternative. This short report documents an emergency LVAD exchange in a 55-year-old man who underwent LVAD (HeartWare Inc) implantation in 2013 as a bridge to transplantation. Four months after the initial surgery, he suffered from a hemorrhagic stroke despite properly managed anticoagulation. On February 17th 2017 he was re-admitted with LVAD pump thrombosis. As fibrinolysis was contraindicated, an emergency pump exchange was performed via a limited thoracic incision in order to minimize surgical trauma, reduce intraoperative complications and facilitate immediate postoperative recovery. This report documents the very first LVAD pump exchange as well as the first one performed via a minimally invasive approach in Poland.
\end{abstract}

Key words: left ventricular assist device, HVAD, pump, excange, HeartWare, thrombosis, mini, minimally invasive.

\section{Introduction}

Left ventricular assist device (LVAD) thrombosis remains a dreadful complication of mechanical circulatory support, with an incidence of $8-12 \%$ depending on the pump type and patient's comorbidities [1]. Fibrinolysis may be considered early in HeartWare pump thrombosis, but when

\section{Streszczenie}

Zakrzepica sztucznej lewej komory serca (LVAD) jest zagrażającym życiu powikłaniem, występującym u 8-12\% pacjentów, w zależności od rodzaju sztucznej komory serca, a także chorób towarzyszących. Fibrynoliza może być przeprowadzona w przypadku wczesnej zakrzepicy pompy, a przy przeciwwskazaniach do jej wykonania wymiana LVAD jest jedyną alternatywą. Przedstawiony opis przypadku klinicznego dokumentuje ratunkową wymianę LVAD u 55-letniego mężczyzny, u którego w 2013 r. wszczepiono LVAD (HeartWare Inc.) jako pomost do transplantacji serca. Cztery miesiące po pierwotnej operacji pomimo prawidłowo kontrolowanego leczenia przeciwkrzepliwego wystąpit udar krwotoczny mózgu. 17 lutego 2017 r. pacjent został ponownie przyjęty do naszej Kliniki z zakrzepicą LVAD. Z powodu przeciwwskazań do wykonania fibrynolizy wykonano ratunkową wymianę LVAD z małoinwazyjnego dostępu, poprzez torakotomię lewostronną, co redukuje uraz chirurgiczny, możliwe powikłania śródoperacyjne, a także przyspiesza rehabilitację chorego. Przedstawiony opis przypadku dokumentuje pierwszą wymianę LVAD, a jednocześnie pierwszą wymianę LVAD wykonaną techniką małoinwazyjną w Polsce.

Słowa kluczowe: sztuczna komora, pompa, wymiana, zakrzepica, małoinwazyjnie.

contraindicated a surgical pump exchange represents the treatment of choice [2].

This short report documents an emergency LVAD exchange due to acute pump thrombosis performed via a limited thoracic incision in order to minimize surgical trauma, reduce intraoperative complications and facilitate immediate post-operative recovery.

Address for correspondence: Remigiusz Antończyk, Department of Cardiac, Vascular and Endovascular Surgery and Transplantology,

SMDZ in Zabrze, Medical University of Silesia in Katowice, Silesian Centre for Heart Diseases, M. Skłodowskiej-Curie 9, 41-800 Zabrze, Poland, e-mail: welik@wp.pl

Received: 11.01.2017, accepted: 13.03.2017. 


\section{Case report}

A 55-year-old man, due to ischemic cardiomyopathy and advanced heart failure, underwent successful LVAD (HeartWare Ventricular Assist Device, HVAD[Siddique, 2013 \#10]; HeartWare, Inc., Framingham, MA, USA) implantation through full sternotomy 4 years prior to the described events. Four months after the initial surgery, he suffered from hemorrhagic stroke despite well-controlled anticoagulation (vitamin $\mathrm{K}$ antagonists (VKA) and acetylsalicylic acid (ASA)). All neurological deficits resolved after prolonged but intensive rehabilitation. Afterwards, the patient maintained the previously ordered anticoagulation regime, with the international normalized ratio (INR) at a therapeutic level. Moreover, the patient was classified as an aspirin responder.

On February $17^{\text {th }}, 2017$ he was re-admitted to our institution with an LVAD alarm indicating overly increased power consumption (12-16 W). Physical examination revealed jaundice and hematuria. Both serum creatinine $(>200 \mathrm{mg} / \mathrm{dl})$ and lactate dehydrogenase ( $\mathrm{LDH}, 2500 \mathrm{U} / \mathrm{l})$ levels were significantly elevated. Markedly reduced left and right ventricular functions (LVEF $=20 \%$; TAPSE $9 \mathrm{~mm}$ ) together with the functioning aortic valve were visualized in echocardiography. Although in an overall good condition, the patient had progressive dyspnea.

Technical tests supported by clinical and laboratory findings indicated significant and propagating pump thrombosis requiring immediate intervention. Due to the past medical history, fibrinolysis was not considered and the patient was rushed to the operating room $3 \mathrm{~h}$ after admission.

The patient was positioned in standard fashion with the left side elevated in general anesthesia with tracheal intubation and mechanical ventilation. A limited incision in the sixth left intercostal space was made, exposing the pericardium. The LVAD pump housing and outflow graft (OFG) were carefully dissected. Four plastic casings protecting the OFG proximal to the pump were removed to facilitate clamping. Extracorporeal circulation (ECC) was established via femoral vessels and initiated once the activating clotting time exceeded $400 \mathrm{~s}$. While on pump, the LVAD was turned off, and the OFG was clamped and unscrewed, but not disconnected, so as to prevent unnecessary blood loss. Then the pump was unscrewed from the sewing ring and removed, with the driveline (DVL) cut. Careful inspection of the left ventricular cavity allowed for removal of circumferential pannus adhering to the inflow cannulation site. Once cleared, the new LVAD was mounted onto the same sewing ring, secured, and connected to the previous OFG (Fig. 1). The driveline was tunneled into the left upper quadrant in the double-stage technique away from the remaining DVL. Once the pump had been de-aired and the OFG clamp removed, the LVAD speed was increased slowly from 1800 to $2700 \mathrm{RPM}$ at $4.1 \mathrm{~W}$ to achieve $5.8 \mathrm{l} / \mathrm{min}$. Concomitant ECC cessation helped achieve stable and predictable hemodynamics with moderate inotropic support. The thoracotomy was then closed, leaving two drains in the left pleural space. The remaining driveline was finally explanted. The patient was moved to the intensive care unit on norma- tive inotropic support, was extubated shortly thereafter, and was discharged home on the $16^{\text {th }}$ postoperative day in good overall condition.

Significant mechanical damage of the impeller due to thrombus accumulation was found during pump disassembly and inspection (Fig. 2).

\section{Discussion}

In cases of pump thrombosis and contraindications for lysis, surgical pump exchange remains a life-saving procedure. A less invasive approach (LIS) via a limited thoracic

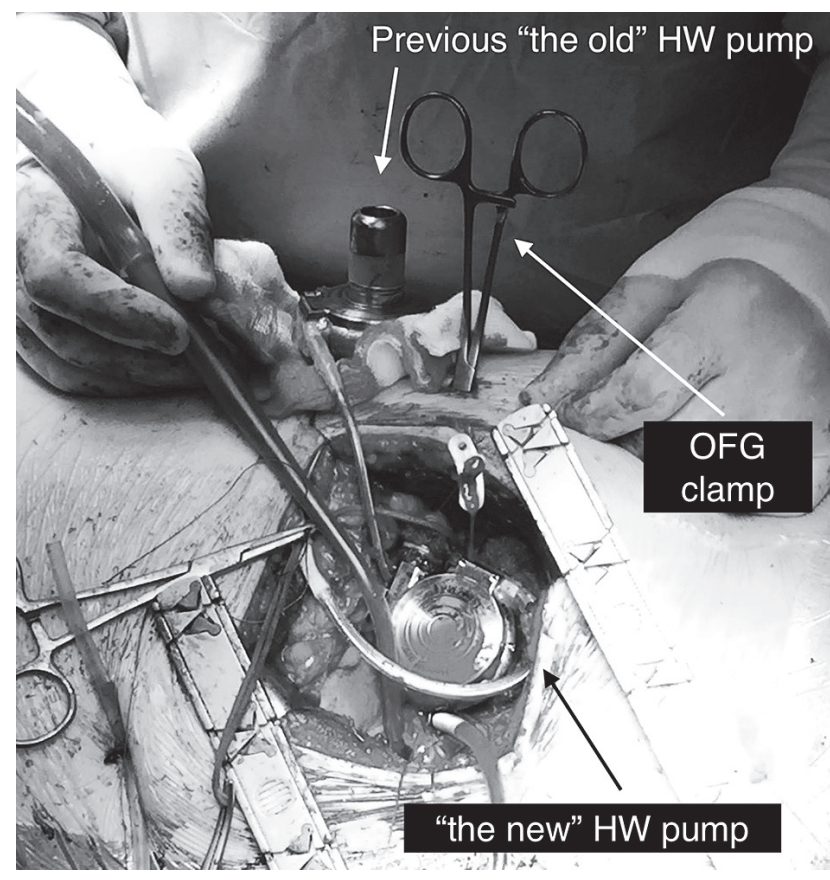

Fig. 1. Left anterolateral thoracotomy. Two HeartWare LVAD pumps during exchange process

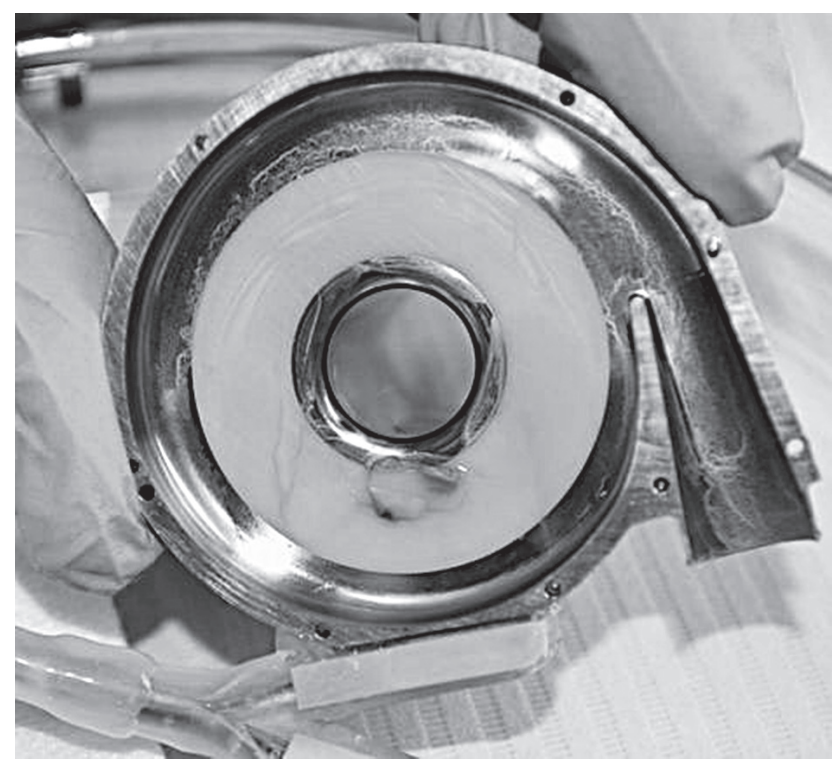

Fig. 2. A thrombus adhering to the hydraulic bearing was found on pump inspection 
approach offers outstanding pump visualization and handling without the necessity of dissection of pericardial adhesions, allowing for reduced surgical trauma and faster patient recovery and rehabilitation [3].

The introduction of rigid sewing rings with the pump housing made the exchange process much easier, as one needs to unscrew one locking screw (HeartWare) or to unlock the lever (HeartMate III) to detach the pump. However, it may represent a technical challenge when an LIS technique is used, especially with the HVAD, as the locking screw is located at an angle difficult to reach with conventional tools. Small in size and therefore less invasive thoracotomy offers excellent visualization of the pump itself, but the inability to reposition the heart leaves the operator little possibility to expose the space between the ring and the pump. However, the screw can be easily reached via a separate $1 \mathrm{~cm}$ incision on the chest wall, small enough to fit the screwdriver provided.

We also encourage leaving the OFG untouched unless infected or severely stenosed. The locking mechanism is different in both the HVAD and $\mathrm{HM} 3$, with a much improved solution in the latter. When OFG detachment and subsequent fixture become challenging, one can consider graftto-graft anastomosis, which might be technically demanding due to limited space. Reaching the OFG with a clamp via the intercostal space is facilitated by a $5 \mathrm{~mm}$ incision on the chest wall just above its position.

Placement and routing of the DVL is performed in the usual fashion, but may be demanding in patients who have suffered from recurrent DVL infections. A separate or alternative route should then be chosen upon thoughtful discussion with the patient.

This report documents the very first LVAD pump exchange in Poland as well as the first one performed via a minimally invasive approach. MOZ together with RA performed the procedure.

\section{Disclosure}

MO Zembala - Consultant for Symetis SA, Vascutek Terumo, Abbott and AtriCure. J. Pacholewicz - Consultant for HeartWare.

\section{References}

1. Nguyen AB, Uriel N, Adatya S. New challenges in the treatment of patients with left ventricular support: LVAD thrombosis. Curr Heart Fail Rep 2016; 13: 302-309.

2. Bartoli CR, Ailawadi G, Kern JA. Diagnosis, nonsurgical management, and prevention of LVAD thrombosis. J Card Surg 2014; 29: 83-94.

3. Iwanski J, Tran PL, Jerman C, Smith R, Kazui T, Khalpey Z. Off-pump left ventricular assist device exchange via re-do left mini-thoracotomy with original outflow graft preservation. Perfusion 2017; 32: 179-182. 